College of Science and Technology, London, during February-December 1959 ; Dr. P. R. Davis, lecturer in anatomy, Royal Free Hospital School of Medicine, London, to enable him to extend his studies of African human skeletal material at Khar. toum, Ibadan and Makerere, to study fossil primate material at Nairobi and to visit fossiliferous sites, for six months from February 1959 ; Prof. C. M. Donald, professor of agriculture in the Waite Agricultural Research Institute, University of Adelaide, to enable him to study recent advances and techniques in agronomic research at Hurley and elsewhere in the United Kingdom, for three months from April 1959 ; Prof. P. C. Dutta, professor of organic chemistry, Indian Association for the Cultivation of Science, Jadavpur, to enable him to gain experience in the field of alicyclic compounds related to terpenoids, at the Imperial College of Science and Technology, London, and Oxford, for about ten months from May 1959; Dr. A. Iggo, lecturer in physiology, University of Edinburgh, to enable him to gain experience of techniques for the analysis of spinal cord activity and to apply these in further investigation of the nature of rhythmic nervous activity in mammals, at Canberra, for about five months from July 1959 ; Dr. L. N. D. Lucas, senior lecturer in physics, University of Western Australia, to enable him to gain experience in the use of electron microscopy to study the microstructure of solids, at several centres in the United Kingdom, for about ten months from March 1959; Mr. I. L. Mason, of the Agricultural Research Council Unit of Animal Genetics, Edinburgh, to enable him to visit Australia and New Zealand for about ten months in 1959 , in order to study animal breeding research there, particularly on beef cattle under tropical and sub-tropical conditions ; Dr. Jean M. Tyler, Imperial Chemical Industries Research Fellow, Department of Chemistry, University of Edinburgh, to enable her to carry out structural investigations on West Indian natural products at Kingston, Jamaica, for a year from April 1959 ; Dr. J. M. Vincent, associate professor of agricultural microbiology, University of Sydney, to enable him to continue his studies of the root-nodule bacteria at Rothamsted, for about eight months during 1959.

\section{The NEw Humanism of Science}

Is science a triumphal march or a stumbling shuffle from one intellectual expedient to another? Mr. Frank Greenaway thinks the latter, and in the Universities Quarterly $(12,130,228$, and 13, 24; 1957-8) compares the modern scientist to a caterpillar tractor, perpetually pulling up his support behind him as he goes. The pseudo-literature of experimental reports exfoliating every week hides the real understanding of science, precludes 'eaves dropping' by other educated men and drives fissures into our intellectual society. "It is a curious thing," he writes, "that while most intellectual people are well aware of a sense of tradition in the things they respect as the basis of their culture, they have very little idea of any tradition in science." As he points out, Copernicus, Agricola and Vesalius published their principal works before Shakespeare was born; most music is younger than modern chemistry, and most plays than the discovery of the electron. Going beyond the "New Humanism" of the late George Sarton, Mr. Greenaway remarks that the scientist has been served by fewer and less able biographers than any of his class of creative thinker, and suggests that there is a great field open to writers to rescue the life of science by rescuing the lives of the scientists and so enable their successors to see science apprehended as a unity.

Mr. Greenaway's closely argued, cogent plea for the restoration of the traditional element in modern conceptual thinking about science presents it as "one of the keys to the new understanding of science which we need". He looks across the fissure to the arts, where the direct relation between the professional creator and amateur assessor continues. He looks ahead to the time when a good scientist will take the trouble to ensure that his paper will survive. Mr. Greenaway mentions Acton; yet might also have included A. L. Rowse, who, though he wrote "I am not merely uninterested, I am positively anti-scientist. I regard it as essentially a specialist activity for people to take to after they have been educated", and could yet say "still, if I had been told something of the fascinating story of mathematies and the men of genius who built up their body of knowledge it would have been quite different".

\section{Bernice P. Bishop Museum, Honolu'u}

THE annual report of the Bernice P. Bishop Museum for 1957, entitled "Concept of the Pacific" (pp. iv +31. Honolulu, Hawaii : Bernice P. Bishop Museum, 1958), follows, as usual, a rather unorthodox pattern. The Pacific has for long been one of the world's major regions of investigation, and it is rightly emphasized that this immense area of ocean, islands and continental margins has a great degree of unity. The report indicates the manner in which the Museum has taken part in research work in the Pacific area, exhibited displays on present and past activities in the region, and makes the interpretation of a knowledge of the Pacific to the public at large its major objective. The chief effort of the year was the installation of exhibits in the Hall of Pacific Life, which is intended to provide a background of the physical geography and natural history of the area.

\section{Engineering Materials and Design}

TuE present era with its ever-increasing rate of advancement in all fields of technology has brought forth many demands for new and better materials and also a great yield of new materials. These two factors are inter-related, but lack of an up-to-date information service has been a serious drawback for the majority of engineering designers. The object of Engineering Materials and Design (1, No. 1 ; October 1958. Pp. 58. Published monthly. Annual subscription 35s.; 5.25 dollars. Single copies $28.6 d$. London : Heywood and Co., Ltd., 1958) is to bring to engineering designers information of new design and material developments in all branches of engineering. This information will be presented in articles, reports and data sheets prepared by authors with first-hand experience. The first issue contains a selection of articles on widely differing topics ranging from uses of titanium and new developments in polyethylene to the selection of fractional horsepower motors and the organization of a modern drawing office. The data sheets included in this number are concerned with molybdenum, polystyrene and new sandwich-material applications. The layout is clear and in contemporary style. If the present standard is maintained, the periodical will succeed in its object. 